\section{Field science in the} Railroad Era: the tools of knowledge empire in the American West, 1869-1916

\section{Pesquisas de campo na era} das ferrovias: os instrumentos do império dos conhecimentos no Oeste dos Estados Unidos, 1869-1916

\author{
Jeremy Vetter \\ Assistant Professor of History, Dickinson College \\ P.O. Box 1773 \\ Carlisle, PA 17013 - USA \\ vetterj@dickinson.edu
}

Submitted on June 2007.

Approved on January 2008.
VETTER, Jeremy. Field science in the Railroad Era: the tools of knowledge empire in the American West, 18691916. História, Ciências, SaúdeManguinhos, Rio de Janeiro, v.15, n.3, p.597-613, July-Sept. 2008.

\section{Abstract}

Focusing on the field sciences during the late nineteenth and early twentieth centuries, this paper analyzes how railroads served as tools of knowledge empire in the American West. The political economy of this region, shaped by the rise of Populism and capitalist development with federal and state government support, provided the context for cooperation between field scientists and railroad companies. Early on, the displacement of American Indians and their concentration on reservations was intertwined with the research of the Bureau of Ethnology under John Wesley Powell. Later, railroad companies became important patrons of field research, primarily through their provision of free or reduced-fare passes for travel. This research ranged from state universities undertaking research in horticulture and irrigation engineering to metropolitan natural history museums whose field work in paleontology had cultural or symbolic value.

Keywords: field science; railroads; John Wesley Powell; American West; economic development.

\section{Resumo}

Ao analisar pesquisas de campo realizadas no final do século XIX e início do $X X, o$ artigo mostra como as estradas de ferro foram instrumentos do império dos conhecimentos no Oeste dos Estados Unidos. A economia política da região foi modelada pela ascensão do populismo e pelo desenvolvimento do capitalismo com o apoio dos governos estaduais e federal. Criaram-se assim as condições para a cooperação entre cientistas e companhias ferroviárias. Num primeiro momento, o deslocamento dos índios e sua concentração em reservas estiveram relacionados às pesquisas do Escritório de Etnologia, então dirigido por John Wesley Powell. As companhias ferroviárias tornaram-se importantes patrocinadoras de pesquisas de campo fornecendo passagens gratuitas ou a custos reduzidos para as viagens dos cientistas, desde aqueles ligados a universidades públicas que promoviam estudos sobre horticultura e engenharia da irrigação, até museus metropolitanos de história natural, cujos trabalhos de campo em paleontologia tinham valor simbólico ou cultural.

Keywords: pesquisa de campo; estradas de ferro; John Wesley Powell; Oeste americano; desenvolvimento econômico. 
$\mathrm{C}$ onsider the seemingly basic question of how scientific fieldworkers got to their field sites. These days, with our dense global network of airline flights and national systems of superhighways, it is easy to forget that as recently as a century and a half ago, even getting across the North American continent was a major ordeal, taking not just weeks but months. While research workers in laboratories - sites rising in scientific prominence since at least the mid-nineteenth century - certainly had to worry about how to bring in various materials for laboratory manipulation, they did not normally have to travel far. Field scientists, by contrast, had to make complicated travel arrangements and endure arduous journeys just to arrive at their knowledge-making sites. Here I will discuss two crucial and interrelated aspects of how scientists got to the field in the late nineteenth and early twentieth centuries: the emerging infrastructural networks - especially based on rail transportation - that enabled them to get there in the first place, and the symbiosis of economic and scientific imperial expansion that framed their work. In examining how these practical concerns influenced the process of knowledge production in the field, this paper traces many different disciplinary traditions in the field sciences, including paleontology, entomology, botany, horticulture, and anthropology.

In conceptualizing this wide range of field science disciplines, I have found it useful to think about scientific practice as organized according to certain common patterns, or modes of knowledge production in the field. The four most common and identifiable modes that were emerging to make field science more systematic during the late nineteenth and early twentieth centuries - during an era of railroads and telegraph lines - were networks of lay observers, surveys, stations, and quarries. While the lay networks and surveys by trained and supervised staff members usually covered large geographical territories, the stations were long-term outposts for producing knowledge in the environment of the field (often connected to practical domains, such as agriculture) and the quarries were intensive sites for extracting scientific materials for processing elsewhere (Vetter, 2005). All of these modes were crucially situated with respect to infrastructures of transportation and communication.

In other words, the field is an engineered space. Just as science 'engineers space' for social and economic activity through its role in communications systems (Barry, 1993), so too do those infrastructures reflexively construct the practice of science, especially science in the field. It is imperative for historians to understand how the field is made, not just found. For field scientists, as for conventional economic enterprises operating within the vast global geography of the natural world, the technologies that facilitate how material things and information move around - the railroad, the telegraph, the postal service - are crucial. The significance of transportation and communication infrastructure in the practice of field science is beginning to attract more attention (Podgorny, 2005; Vetter, 2004). The roles of railroads, telegraphs, and other technologies as 'tools of empire' and 'tentacles of progress,' in the phraseology of Daniel Headrick $(1981,1988)$, have been widely recognized as central to understanding how global empires were created and maintained. The same could be said for expanding knowledge empires, in the American West and elsewhere.

Recognizing the significance of such tools need not consign us to any kind of unitary technological determinism. Headrick (1981) himself argues for the interacting roles of 
both means and motivations and thus proceeds "by analyzing the technological changes that made imperialism happen, both as they enabled motives to produce events, and as they enhanced the motives themselves" (p.11). Likewise, the expanding knowledge empire of the late nineteenth and early twentieth century depended on both the means provided by tools, such as the railroad, and the motivation provided by the interlocking visions of economic development shared by field scientists and railroad officials alike.

In an earlier paper, I traced how scientific field work in the US Central West expanded and changed after the building of the transcontinental railroad in the late 1860s. The railroad not only affected the practice of field science in a fundamental way, but it also transformed the natural environment studied by field scientists along the railroad corridor and brought scientists into close interaction with business men (Vetter, 2004). It is the last point - the relationship between science and business in the form of railway companies that I will focus on in this paper. As the first exemplars of modern large-scale business organization in the nineteenth century (Chandler, 1977), the railroads provide an important lens for viewing the expansion of the American scientific empire into the interior West.

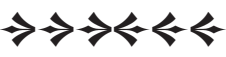

Why would railroad officials have wanted to support scientific field work in the American West? In answering this question, it is essential to consider the political context of the late nineteenth and early twentieth century United States, especially in the interior West. For not only was this period a time of growing public authority for science but more specifically it was also a time of Populist agitation against big business, especially during the 1890s. Railroads were under attack by leaders of the People's Party (the Populists with a capital ' $\mathrm{p}$ ') and populist-minded leaders of the conventional political parties. The railroads were the "Leviathans with tentacles of steel", in the words of the Kansas Populists analyzed by Thomas Frank (1989). Populists challenged the private ownership of the railroads and lambasted the oppression of the ordinary farmer (and often also the worker) by the largescale organization of the corporate business form.

The manager of the western lines of the Burlington \& Missouri Railroad - stretching through Nebraska into Colorado, Wyoming, and eventually South Dakota and Montana - was George W. Holdrege, and he was one railroad official who worked very hard to battle the Populists. A biographical account of his leadership in railroad development for over five decades describes his response this way:

Holdrege stated that he believed the best way of ending the great political strength in the West that threatened the existence of the private railroad companies [i.e. the Populists and their sympathizers], was to find some solution to the basic agricultural problem which confronted the region. As there was little chance that the farmers in Nebraska had either the money or the time to invest in the pursuit of agricultural experimentation, he advanced the plan that this task be taken over by the Burlington in the hope that some discovery could be made that would point the way to prosperity for the region (Davis, 1950, p.214).

In other words: scientific knowledge instead of Populism. Holdrege was one of many railroad officials and other business leaders (not to mention scientific and political leaders) 
who held this view. While Holdrege's company and several other railroads invested directly in their own experimental farms and indirectly in the research of dry-farming promoters such as Hardy Webster Campbell, they also supported the work of a wide variety of field scientists in the region to produce knowledge across the spectrum of disciplines, from the practical agricultural sciences to those, such as paleontology, that offered more symbolic or cultural resources.

This approach dovetailed nicely with the effort to bring more settlers to the regions opened up by the expanding railway empires in the American West. After the building of the original transcontinental railroad in the late 1860s - the Central Pacific from the California coast to Utah, connected to the Union Pacific from Utah to the Missouri River - several other transcontinental rail lines followed. The railroad companies became even more intensely interested in promoting economic development as the fully transcontinental traffic became increasingly divided among them. In the words of Gardiner G. Hubbard (1887), who in a Science article described the five North American transcontinental lines, the original Union Pacific-Central Pacific line, "when built, relied almost entirely upon the through business, [but] now mainly upon local business, as the through business has become of comparatively little importance because it is divided among five lines" (p.136). While railroad efforts to promote economic development possibilities along their lines went back much earlier (Gates, 1934; Greever, 1954; Hedges, 1926, 1928; Jones, 1949; Mickelson, 1993; Overton, 1941; Ziedel, 1993), it was in the 1890s and early 1900s that railroad companies turned especially to science as a solution to their political and economic problems.

\section{$\rightarrow \rightarrow \rightarrow<<$}

But first, any study of the colonial aspects of the American West, whether focused on the history of science or anything else, must in some way grapple with the problem of how white settlers displaced American Indians from much of the region's land. The human sciences provide a window into how the railroad functioned as a tool of imperial science - and how the science of ethnology functioned to prepare the way for scientific and railroad expansion. One can think about an explorer and government scientist such as John Wesley Powell riding by railway and on horseback through the thinly inhabited canyon lands, mountains, deserts, and valleys of Colorado, Wyoming, and especially Utah (Worster, 2001). First gaining adventure celebrity status after his leadership of an expedition down the Colorado River in 1869, Powell followed up not only with a second descent of the same river a couple years later but also through extensive overland field work as one of the four 'great survey' captains (along with Ferdinand Hayden, George Wheeler, and Clarence King) sponsored by the US government to make topographical and geological maps of the interior West. Although anthropological research was not ostensibly Powell's central task, it was nevertheless a matter of great personal and intellectual interest. In fact, Powell later became the first leader of the Bureau of Ethnology when it was founded in 1879 (its name was changed to Bureau of American Ethnology in the 1890s). His earlier field observations of American Indians in the West may have seemed like icing on the cake of physical scientific research that was his primary official charge, 
but they were conceptually fundamental to effective state control in the displacement of American Indians by railroad-based economic development.

As a scientific survey leader in the 1870s, Powell was aided to no small degree by the expansion of the Union Pacific Railway across Nebraska, Wyoming, and Utah in the late 1860s. It was the Union Pacific Railway that brought Powell to Salt Lake City in the spring of 1873, when he and George Ingalls, an Indian agent in Nevada, were asked by the federal government to investigate and make recommendations for the nomadic Indian tribes of Utah and Nevada, as skillfully analyzed by Scott Kirsch $(1999,2002)$. The government's urgency stemmed from its fear that the violent resistance of the Modocs in southeastern Oregon and northern California would spread. To solve a pressing problem in its administration of subjugated people in the colonized West, therefore, the US government turned toward field scientists like Powell to propose solutions. After several months of study, Powell and Ingalls submitted a report to Congress recommending the consolidation of the Shoshones, Utes, Paiutes, and other tribes of the Great Basin into a limited number of reservations that the US government could feasibly manage and protect against settler incursions. At least as much as data collectors, Powell and Ingalls also acted as promoters of the reservation system to the Indian groups they encountered. They faced an uphill battle with tribes whose subsistence, livelihood, and cultural traditions revolved around frequent movement to take advantage of the thin, scattered resource base of the interior American West.

Although Powell could reach Utah on the Union Pacific, meeting with Indians also required arduous travel on horseback with supply wagons on simple dirt roads, far beyond the existing network of railroad and stagecoach lines that had accompanied the expanding American continental empire. The Uintah reservation in eastern Utah, for instance, could be reached only by a treacherous road from Salt Lake City that was closed in the winter time. Powell himself was further delayed by several days in reaching the area because of snow blocking the railroad to Salt Lake City. In a June 1873 letter recommending that various Indian groups be relocated to the Uintah Indian Reservation, Powell made a point of emphasizing the problem of road access:

One of the serious difficulties on this agency [the Ute Agency] is the want of a good road by which to reach the settlements. Supplies are now hauled over the Uintah mountains, crossing difficult and rapid streams again and again, and the road is travelled with much labor and great expense. A road can be made from the agency to Green River Station, or to some point further to the east, at less cost than to build a road over the Wasatch Mountains to Salt Lake City, the road now travelled. And there would be other advantages, in that the road to the northeast could be used in winter and the distance to the railroad shorter (Powell, 1874, p.111).

Realizing the importance of these transport lines not only for investigators such as himself to access the land - and here, one should remember that Indian reservations were almost by definition located in places that were least accessible to the invading American settlers - but also for bringing in the provisions that the US government was realizing it had to give to the displaced Indians to keep them from starving, Powell therefore recommended building a better access road to link up with the Union Pacific Railroad, further north and east in Wyoming. 
Convincing the nomadic Indian tribes of the Great Basin to settle on reservation lands was daunting enough; their persistence there was yet another problem. Powell tried to increase their likelihood of their remaining on reservations by gathering knowledge that would suggest which groups would get along best when placed in close proximity. For Powell, this task involved the collection of data on the historical and cultural affinities of various groups, especially as revealed through languages. As Powell himself put it during testimony to the Allison Commission of the US Congress in the mid 1880s, the

\begin{abstract}
linguistic differences among tribes lead to many complications in the administration of Indian affairs. ... The Indians who speak languages of the same stock have common traditions, common mythologies, common religions, \&c., and are classed together. They are usually friends, or can be made friends and brought together under one administration, while Indians belonging to distinct linguistic stocks have distinct traditions, mythologies, and religions, and consider themselves distinct peoples, and are often hereditary enemies (Powell, 1885, p.192).
\end{abstract}

He added that "such feelings are much stronger in savage races than amongst civilized peoples" (p.192).

The classification of American Indian groups by their languages, in fact, became a central preoccupation of Powell's anthropological life work, well beyond his own years as a field surveyor. As the first director of the Bureau of Ethnology, Powell issued an introductory guide to the study of American Indian languages, hoping to encourage and instruct other field workers in a common set of words and phrases, research techniques, and reporting formats (Powell, 1880). Studying language was crucial not just to classifying Indians and rendering their diversity legible to the federal government but also to the larger 'assimilationist' goals that he and other leaders championed, in which Indians would adopt the white society's language and culture, including capitalist property norms. In Powell's judgment, as expressed in the Bureau's first annual report, the three keys to civilizing the Indian were family ("inheritance in lineal descent"), property (severalty over communal), and language (English). The federal government had shown its "justice and beneficence" through its "extinguishment of the vague Indian title to lands and granting to them of lands for civilized homes on reservations and in severalty, in the establishment of schools, in the endeavors to teach them agriculture and other industrial arts" (Powell, 1881, p.XXIX-XXX).

In subsequent years as head of the Bureau of Ethnology, Powell continued to put the highest emphasis on the study of language, which he saw as key to learning about all other aspects of culture, both for government administration and assimilation into American capitalist society. "Without fundamental knowledge of those languages which can still be sufficiently studied", he contended, "all other anthropologic peculiarities of the tribes speaking them will be imperfectly understood" (Powell, 1883, p.XX). The research priorities of the Bureau reflected this emphasis on linguistic studies, and each year Powell sent out field researchers to study American Indian languages. Several years later, Powell articulated the philosophy behind this approach, discussing the Bureau's activities as follows:

On considering and testing the applicability of the demotic characters of the Indians, it was soon found that tribes speaking the same or similar languages are at peace more frequently than are tribes of diverse tongues; that similarity in language generally accompanies similarity in tribal organization and law, while similarity in language and law is commonly connected 
with similarity in beliefs and arts; and that peoples similar in these characteristics can be combined on reservations without engendering strife (Powell, 1896, p.XXVIII).

Based on his experience as a government scientist making practical recommendations for the administration of relations with the indigenous people of the American West, Powell (1896, p.XXIX) concluded that "in general, language alone served as a satisfactory basis" for classifying Indians to concentrate "them on reservations, since clans of remote habitats speaking the same tongue soon find themselves dominated by a common or at least related law and religion constituting a self-evident bond of sympathy and ultimate union" (p.XXIX). It was therefore based on linguistic knowledge that the Indians "were grouped and from time to time assembled on reservations" (p.XXIX). Such a long-term vision allows us to extend and deepen Kirsch's (2002) account based on the critical historical geography of Powell's direct participation in such activities to consolidate American Indians on reservations in the 1870s.

Prior to the bulk of the cooperative work that linked science to railroad-based economic development, ethnological knowledge was crucial in facilitating Indian concentration on reservations and assimilation to the American capitalist model of private property ownership. Even if the transport system played only a limited role in such efforts - and, as the evidence above makes clear, it was at least part of the picture - the wider capitalist developmental context in which the railroads played a leading role was inextricably linked to the dispossession of Indians from the lands and resources of the American West. Even (or especially) when examining a government scientist such as Powell, whose developmental agenda for the interior West was heavily influenced by his suspicion of private business interests, these aspects of the problem must not be ignored.

\section{$\rightarrow \rightarrow \rightarrow<<$}

As I noted above, my focus in this paper is on the relationships between scientists and railway officials in the development of the American West. A broader, cultural treatment of the problem is certainly possible (and desirable), but for the remainder of this paper I concentrate mainly on the direct logistical and practical support of a wide range of field science by railroad companies. To be specific, many of the field scientists in the American West in the mid to late nineteenth century received free or reduced-fare travel passes from the railway companies. Some of the most frequent users of free pass privileges on the railroads in the American West were the researchers and instructors at state universities. The close connection between their field work and the economic development of the region made it a natural target of railroad support.

One such regional researcher was Frederick W. Taylor, who was born in 1860 in what was then still Nebraska Territory. After starting his career in the nursery business, in 1891 Taylor accepted a professorship in horticulture at the University of Nebraska. In addition to his on-campus teaching duties, Taylor was very active in promoting fruit growing in Nebraska, both on the supply side through extension work and farmers institutes, on the one hand, and on the demand side through exhibits of Nebraska produce at various fairs and expositions, such as the famous one in Chicago in 1893. In the course of doing this 
work, Taylor often received assistance from the railroads. In the summer of 1892, for example, he solicited a railroad pass from the Burlington line for one of his graduate students "to do some investigating among the trees and fruits in North west Nebraska" as part of preparing the State Horticultural Society report, which simultaneously served as a scientific research document and as a text for promoting the possibilities of fruit growing (Taylor, 21 June 1892). A few months later, during the early fall season of country fairs, Taylor again asked the Burlington for a railroad pass, this time for one of his associates so that he could "get together a good exhibit of Nebraska fruit, for the Worlds Fair" in Chicago the following year (Taylor, 26 Sept. 1892). In another case, Taylor asked the Burlington to transport his representative to Denver, in the nearby state of Colorado, to attend the annual meeting of that state's horticultural society (Taylor, 2 Dec. 1892).

Taylor relied not just on the Burlington line but also on other railroads that ran through Nebraska. In January 1894, for instance, he wrote the general manager of the Chicago, Rock Island, \& Pacific (CRI\&P) in Chicago asking the company to renew his railroad pass. In making his request, Taylor indicated both his dependence on railroad company generosity to accomplish his field work and his conception of the link between scientific research and economic development that would benefit the railroad lines:

\footnotetext{
I have a great many calls to go to different parts of the state, to give information regarding fruit raising, and have no salary or allowance for expenses to cover such work. I do a great deal of it, however, and am willing to do so, when it does not mean cash expense. Most of that would be for R.R. fare, of course.

I may say that I have B.\&M. [i.e., Burlington \& Missouri Railroad] transportation, and that that line and your own, cover most of the state in which there is a decided interest in fruit growing. This interest is continually growing, as was shown be [sic] the large attendance at our meeting, recently held, a report of which I shall be pleased to send you as soon as issued. I trust you may issue this transportation, as I desire to reach some of your territory soon (Taylor, 30 Jan. 1894).
}

By raising the possibility of fruit development in the CRI\&P's 'territory,' Taylor made clear the reciprocal benefits of the exchange relationship between field scientists and railroad companies. In addition to the intangible benefits of promotion, Taylor also offered the tangible evidence of a written report from a meeting with potential fruit growers. While the document recording such a meeting might not be quite an example of new knowledge production for the benefit of the railroads, at least it could serve to verify how state university researchers like Taylor were working to use their scientific knowledge to promote economic development.

In other cases, the link between railroad travel and the production of new knowledge was more immediate. In the summer of 1894, for instance, Taylor wrote the Burlington line once again for a railroad pass, this time for his University colleague O.V.P. Stout, a professor of civil engineering. The fact that Taylor wrote instead of Stout himself suggests that personal connections and trust relationships were often important along with scientific credentials to secure such reciprocal bonds. In any event, Stout was "planning to make a special study, during vacation, of the question of irrigation, with special reference to what is to be found in the way of supply of water in the streams of the south-west part of the 
state". He needed the railroad pass so that he could measure stream flow "several times during the summer", which would ordinarily be an expensive proposition if he had to buy railroad tickets for each of these journeys. Taylor pointed out that the results of Stout's research would be made available in a "bulletin for free distribution", presumably making it clear that they could positively influence the economic development of the state through the communication of that knowledge to potential settlers and investors. Taylor told his friend at the Burlington that Stout's research would greatly benefit from the company's donation of a pass for the entire summer over all its lines. "I am sure that by doing so you will be encouraging investigation in a line which promises great returns", he noted (Taylor, 2 June 1894). Thus, for both Taylor the horticultural researcher and for his colleague in irrigation engineering, the link between scientific field research and economic development along railroad lines was immediate, obvious, and reciprocal.

The available evidence suggests that Taylor was by no means an anomaly among field scientists engaged in knowledge production that was closely related to economic development. Consider the example of Lawrence Bruner, an entomologist at the University of Nebraska. His papers document the close relationship between field science and railroads, including everything from a Burlington \& Missouri freight bill from September 1904 for books, a USDA note on how to properly document expenses for railroads indebted to the US government, and lots of railroad passes. ${ }^{1}$ While Bruner may have paid some passenger fares and freight bills himself, his correspondence indicates that the railroad often provided free - or at least half-fare - passes for work that promised to promote economic development. In August 1896, for example, Bruner wrote to officials at the Fremont, Elkhorn \& Missouri Valley and the Burlington \& Missouri lines in order to secure half-fare passes for a colleague traveling around the state to participate in University extension work (Bruner, 5 Aug. 1896; Taylor, 3 Aug. 1896).

Beyond Nebraska, too, the seeking of railroad passes by agricultural scientists and engineers at state universities was a fairly common practice. At the Utah State Agricultural College (now Utah State University), experiment station director John A. Widtsoe sought annual passes for himself and the station's agronomist, Professor L.A. Merrill, who needed to travel a lot in order to visit experimental farms scattered around the state (Widtsoe, 22 July 1903). After receiving the desired passes, Widtsoe thanked the official of the San Pedro, Los Angeles and Salt Lake Railroad who had provided them, intending that "the results of the work will fully justify the favor you have shown us" (Widtsoe, 30 July 1903). Similarly, the director of Nebraska's main agricultural experiment station located at the University in Lincoln, E.A. Burnett, secured a pass for the researcher who managed Nebraska's first branch experiment station located in the western part of the state near the Union Pacific railroad town of North Platte (Burnett, 23 Aug. 1904). In addition, the railroad company also offered "free transportation on [a] thrashing machine" for the North Platte branch station "if they receive previous notification of shipment" (Burnett, 27 July 1905). The Union Pacific railroad line thus acted as a conduit for the movement of both personnel and equipment, effectively functioning as a "tool of knowledge empire" for the expansion of field science in the Great Plains. Managing branch stations effectively - and attracting extra support for their operations - completely depended on their being situated along railroad lines. 
The connection between field science and railroad-based economic development may be easiest to explain for practical disciplines such as horticulture, agronomy, entomology, and irrigation engineering. But such reciprocal relationships extended to other types of research as well. Even when an immediate practical benefit for land settlement and utilization was not so obvious, the symbolic benefits of associating railroad activities with scientific research could still be high enough - and the friendships between field scientists and railroad officials robust enough - to convince them to cooperate. For an intermediate case, consider botany. As a science that studied wild or native plants more than cultivated plants, botany's practical relevance was not as direct. Nevertheless, railroad companies underwrote botanical collecting activities in the field to compile state floras and other research publications. The University of Wyoming's Aven Nelson, for instance, received railroad tickets on many separate occasions over at least a four-year period from the Union Pacific Railroad for his work on that state's flora (Lomax, 24 Apr. 1897, 26 Apr. 1901, 6 Nov. 1901). It seems that these favors were extended to Nelson in particular, probably due to a combination of his personal friendship with railroad officials and his special reputation as an authority on the botany of the Rocky Mountain region. Others apparently were not viewed as worthwhile recipients of such aid. When Union Pacific official E.L. Lomax replied to one of Nelson's requests, he inquired further if the railroad transportation was for Nelson himself or someone else. "If for the latter we shall have to decline", wrote Lomax, but "[if] you are on a botanical mission in the interest of the University of Wyoming, and desire this transportation personally, we will be pleased to arrange as you request" (Lomax, 3 June 1901). Apparently, the request was indeed for Nelson himself, since the next letter in the botanist's file indicates the enclosure of a "500 mile book, good until Sept. 15th, between Laramie and Cheyenne" (Lomax, 10 June 1901).

As Lomax's reply above suggests, Nelson's association with a state university may have also played a role in the railroad company's inclination to do favors. Railroads were the objects of harsh criticism during this period by Populists and others for operating against the public interest, so it is perhaps understandable that company officials would be eager to portray themselves in support of the work of field scientists at public universities. Their service to the state was thus not purely for promoting economic development within the territories served by their lines but also for the cultural purpose of showing their support for the state's public institutions and hitching themselves to a new generation of universitybased researchers who were promoting their own work as a form of science in the public interest. Thus, when P.A. Rydberg of the New York Botanical Garden wanted to collect plants in southern Colorado in 1900, he sought the assistance of his former state university teacher, University of Nebraska botanist Charles Bessey, to obtain a railroad pass to that region. In return, Rydberg offered Bessey "one of the best sets of plants of my collection" for the University of Nebraska (Rydberg, 13 Mar. 1900). Securing free or reduced fare transportation was crucial to the success of scientific field work, and that, in turn, required a personal connection or perhaps affiliation with a regional institution.

Even botany, whose main knowledge products might be considered only partially relevant for economic development concerns, had its own occasional linkages to direct railroad promotional activities. As the more conventional sectors of farming, ranching, and mining 
were increasingly joined by a burgeoning tourist industry, botanical knowledge became newly relevant. For example, in 1909, E.A. Abbott of the Chicago, Burlington \& Quincy Railroad asked University of Colorado botanist Francis Ramaley to contribute accounts of the flowers around the emerging mountain resort town of Estes Park. At first, Ramaley tried to convince the railroad to fund a new publication, but the company had only such "a small amount" for the purpose that Abbott asked instead for "some brief article on the subject that [Ramaley] would give me the privilege of using" (Abbott, 25 Oct. 1909). Abbott was pleased with the article Ramaley sent him, commenting that he was "greatly indebted" and that the "article covers the subject admirably". At the same time, Abbott also revealed the expectations his company had for the promotional value of such botanical knowledge: "Perhaps it might have been well to have had one paragraph which would have spoken in a general way of the large variety of flowers in Estes Park and their great abundance during the whole summer season some flowers being found at a low altitude at one time of the summer and at a higher altitude at a different time" (Abbott, 8 Dec. 1909).

Whatever the divergence in perspective between a botanist and a railroad promoter, it is nevertheless clear that knowledge from the field sciences could contribute in a wide variety of ways to the economic development agenda of the western railroads. In fact, tourist guides to the American West often contained scientific information. In at least one case the American geological railway guide of 1879 - the entire guide was organized around scientific descriptions of the formations passed en route (Macfarlane, 1879). Later, the US Geological Survey published a series of railroad guidebooks following various transcontinental railway routes that served an obvious tourist agenda (e.g., Campbell, 1915; Lee, Stone, Gale, 1915; Darton, 1915). Thus, at both the state and federal levels, field scientists participated in the project of promoting economic development along railroad lines.

So, then, was it always essential for field scientists involved in reciprocal relationships with railroad companies to be government officials or at state universities? Not necessarily. There were exceptions, such as Edwin A. Popenoe of Topeka, Kansas, a local private college instructor, who took several butterfly collecting trips to western Kansas on the Atchison, Topeka, and Santa Fe Railroad, "thanks to Mr. A.S. Johnson" of that company (Popenoe, 1876 , p.21). Undoubtedly, there were examples of scientists in a variety of institutional settings whose friendships with railroad officials enabled such favors to be exchanged. But perhaps the most enduring and significant examples of mutual benefits exchanged between field scientists and the railroads were in the great urban museums. In cities such as New York or Pittsburgh, museum directors were socially connected with influential officials or financiers in the railroad business, and their field activities became the object of great support from these friends, for primarily symbolic and cultural rather than practical reasons. One of the most popular field sciences for philanthropic support by railroad companies was paleontology, due to the potent combination of public visibility of its large mammal and dinosaur finds (which attracted railroad officials) and the high cost of transporting these large objects and the personnel to extract them (which gave paleontologists a strong incentive for such collaboration). For field paleontologists and museum directors, among their most valuable friends in the capitalist world were those in the railroad business. 
One can trace the cozy relationship between scientific fossil hunters and the railroads in the American West back to first wave of paleontology, the 'fossil war' between E.D. Cope and O.C. Marsh in the 1870s and 1880s. A more senior early rival of both Marsh and Cope, Joseph Leidy (before he withdrew from the field and let the two young, ambitious competitors fight it out), received passes on multiple railroads while working under Hayden in the late 1870s (Leidy, 13 Aug. 1877). Similarly, as George Bird Grinnell recalled a few decades later, he had "always suspected" that some of Marsh's wealthy business friends, "being railroad men, had given Marsh either free transportation for his party or at least rates much lower than those usually in force" (Grinnell, 1923, p.330). In a competitive struggle for access to the fossil resources of the American West, connections with business men - especially railway officials who could provide transportation - might be as important as any other practical asset. The connection between railroad lines and fossil digging in the American West was nowhere more obvious than in the event that was probably the most elaborate example of railroad-supported field science: the great Fossil Field's Expedition of 1899. Sponsored by the Union Pacific Railroad to lure fossil hunting parties to its sparsely populated territory in southern Wyoming with free rail transportation from Chicago, this event brought together field parties from universities, colleges, and civic museums, approximately one hundred field collectors in all (Vetter, 2004, p.197).

More enduring and consequential for the development of museum paleontology was the ongoing relationship between the Carnegie Museum of Pittsburgh and the railroad men who supported its field expeditions. William J. Holland, director of the Carnegie Museum, used his social connections with wealthy businessmen to secure free transportation on railway lines in and out of the rich fossil regions of the American West for his Museum's field collectors. In return, the Carnegie Museum did various favors for the railroad companies, such as providing a pamphlet outlining the geological features of the main Union Pacific line between Nebraska and Utah (Vetter, 2004, p.205-206). Railroad passes were especially useful for helping field paleontologists engage in reconnaissance work, which involved prospecting for new quarry sites over vast geographical territories. Such travels would have been extremely expensive without railroad passes, and the necessity of such a tool of knowledge empire is clear from the museum correspondence. In May 1901, for instance, Carnegie Museum field paleontologist John Bell Hatcher emphasized the importance of prospecting for future fossil digging sites. "If you will procure me a pass over the C.B. \& Q. from Crawford, Neb. to Billings, Montana \& return to Denver", wrote Hatcher, "I will go up \& have a look at those Tertiary \& Cretaceous localities in Montana" (Hatcher, 24 May 1901). Once in Montana, Hatcher wrote Holland once again asking for "a pass for me from Denver to Chicago via Canon City over the Santa Fe R.R. \& when I am through here I will go to Canon City \& see Utterback again \& thence to Pittsburgh" (Hatcher, 17 July 1901). Thus, whether for prospecting or for supervising field parties, the vast distances traversed by field scientists such as Hatcher made railroad passes a crucial part of the Museum's field practice.

The transport of scientific specimens was the other crucial aspect of railroad support for field paleontology. Dinosaur and large mammal fossils were unusually large objects. Shipping them east to an urban center such as Pittsburgh would ordinarily be an expensive 
proposition. Even with the support of railroad companies, arranging for fossil shipments from disparate western quarry sites - located on different railroad lines - was a logistical challenge. The note that Hatcher wrote to Holland at the conclusion of 1903 summer field season reveals the complicated choreography involved:

\begin{abstract}
Please write George B. Harris, President C.B.\& Q. Railway, Chicago, Illinois, requesting that a car be placed at our disposal at Billings, Montana on or before October 20th, where it will be loaded with the collections made by myself, Mr. Douglas, and Mr. Utterback. After loading at Billings, Montana, the car taken to Clearmont, Wyoming and side-tracked there to receive the collections made in that region during the early part of the summer by Mr. Utterback, after completing the loading of the car at Clearmont have same transported to Chicago and there turned over to whatever railway it may be deemed expedient for transporting the collection to Pittsburgh. Also write Mr. A. Darlow Union Pacific Offices, Omaha, Nebraska, requesting that a car be placed at our disposal at Winona, Kansas, on or before October 20th to receive the collections made there during the summer by Mr. C.W. Gilmore, and have the car transported from Winona to Council Bluffs, and there turned over to the Chicago and Northwestern, or such other connecting lines as we may designate (Hatcher, 2 Oct. 1903).
\end{abstract}

As a practical matter, bringing together fossil collections from several different western states seems not that much different from an industrialist wishing to bring together raw materials from various places. In either case, the railroad infrastructure was absolutely crucial. And the involvement of the railroad companies in producing the symbolic, cultural resources of great museum exhibits was no trivial matter. The expanding American knowledge empire was built with tools that often linked science with the models of largescale business organization.

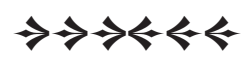

The railroad was a tool of knowledge empire. Railroad-based science was revolutionary not merely in the obvious yet extremely significant sense of greatly speeding up access to the field, but also in transforming the environment (both human and natural) along the railway corridors, as well as serving as site for mutual support and idea trading between railway company leaders and field scientists, especially geologists. Here I have focused primarily upon the last of these effects, since it demonstrates that the westward expansion of American science - its 'imperial' dimension - was based at least as much on close ties to the business world as it was to the extension of governmental authority over territory and people.

Since this paper has focused especially on the relations between field scientists and the business world, in the form of railway companies, it should also remind historians of science of the analytical urgency of linking together the capitalist world-economy with the expansion of scientific empire. Such a relationship presupposes the larger context of geographical relations that provided the structural framework for the expansion of science - along with capitalism and state power - into new territories. Colonial relations in science have inspired diverse approaches, some modeled after the simple stage theories of modernization (e.g., Basalla, 1967), others after the more sophisticated historical and economic geography of Fernand Braudel (e.g., Polanco, 1990, 1992), and still others whose advocates are skeptical about the fruitfulness of such translocal model building (e.g., 
Chambers, Gillespie, 2001). I am inclined to favor something closer to Polanco's Braudelian model, but based more on the world-systems approach of Immanuel Wallerstein (1974, 2004), in which a geographical hierarchy of core, semi-periphery, and periphery - along with an 'external area' into which the world-system has not (yet) penetrated - structures long-distance relationships. The expansion of either capitalism or science on land frontiers such as the American West (or Brazil - see Figueirôa, Silva, 2001) was thus not so much the transmission of science from one region to another as the ongoing relational exploitation of one region by another.

Some readers, especially within the history of science, might think that showing the relations between science and empire - along with its underlying capitalist political economy - is a well-worn story, little worth any effort to retell once again. Yet if recent work in the railroad history of the American West is any indication, development schemes based on scientific expertise still often retain an aura of assumed purity and nobility. For example, Richard Orsi (2005), in his recent magisterial history of the Southern Pacific Railroad during this period, treats that company's support for expertise-based land development, water development, scientific agriculture, and conservation as prima facie evidence that its actions corresponded with a broader 'public interest'. That inference serves, in turn, to underpin his revisionist account of the Southern Pacific as largely a force for progress in the American West - not the oppressive Octopus, as it was so often portrayed. While recognizing "some contradictions and inconsistencies of policy and action", he asserts on the basis of voluminous archival evidence that the company "promoted more organized, efficient settlement, economic development, and more enlightened resource policies in its service area" (p.XIV). Yet from what I have shown in this article, it seems clear that science's relation to railroad-based economic development cannot be simply taken at face value as unproblematic. Instead, the ties of mutual interest binding railroads and field scientists deserve special analytical scrutiny.

To be sure, not all recent railroad history eschews a more critical examination of the political economy of science. Recognizing that scientific expertise was not so much a proxy for progress or the public interest as a contested zone of competing visions for science, Clare Strom's (2003) account of the Great Northern Railway, for example, rests on a sophisticated analysis of the scientific research sponsored by railroad magnate James J. Hill. By exploring the role of business goals in the organization of scientific research on the northern Great Plains, Strom demonstrates how Hill struggled for control over defining what agricultural science would mean in the region. "Hill's quest for agricultural authority proved elusive", argues Strom, "not only because of his own inadequacies but also because of the changing nature of expertise during his lifetime" (p.156). As Strom's account suggests, even though railroad industry leaders might not be fully successful in constructing science as they wished, they nevertheless acted as interested players in the shaping of expert knowledge. This contestation over the meaning of science for the development of the American West indicates the continuing relevance of historical accounts to probe the linkage between science, empire, and capitalism.

\section{NOTE}

${ }^{1}$ Lawrence Bruner Papers (RG 8/12/10), Box 8, Folder 2, Archives \& Special Collections, University of Nebraska-Lincoln Libraries. 


\section{REFERENCES}

ABBOTT, E.A.

Letter to Professor Francis Ramaley. Francis Ramaley Papers, box 1, folder 10, Archives (University of Colorado at Boulder Libraries). 8 Dec. 1909.

ABBOTT, E.A.

Letter to Professor Francis Ramaley. Francis Ramaley Papers, box 1, folder 10, Archives (University of Colorado at Boulder Libraries). 25 Oct. 1909.

BARRY, Andrew.

The history of measurement and the engineers of space. British Journal for the History of Science, London, v.26, p.459-468. 1993.

BASALLA, George.

The spread of Western science. Science,

Washington, v.156, p.611-622. 1967.

BRUNER, Lawrence.

Letter to Mr. J.R. Buchanan. Lawrence Bruner Papers (RG 8/12/10), box 15, Archives \& Special Collections (University of Nebraska-Lincoln Libraries). 5 Aug. 1896.

BURNETT, E.A.

Letter to Superintendent W. P. Snyder. Agricultural Experiment Station Records, North Platte Experiment Station (Correspondence), (RG 10/14/1), box 9, Archives \& Special Collections (University of Nebraska-Lincoln Libraries). 27 July 1905.

BURNETT, E.A.

Letter to Mr. W.P. Snyder. Agricultural Experiment Station Records, North Platte Experiment Station (Correspondence), (RG 10/14/1), box 9, Archives \& Special Collections (University of Nebraska-Lincoln Libraries). 23 Aug. 1904.

CAMPBELL, Marius R. et all.

Guidebook of the western United States. Part A. The Northern Pacific route, with a side trip to Yellowstone Park. Washington D.C.: United States Geological Survey (Bulletin 611). 1915.

CHAMBERS, David Wade; GILLESPIE, Richard. Locality in the history of science: colonial science, technoscience, and indigenous knowledge. Osiris, Washington D.C., v.15, p.221-240. 2001.

CHANDLER, Alfred D.

The visible hand: the managerial revolution in American business. Cambridge: Harvard University Press. 1977.

DARTON, Nelson $\mathrm{H}$.

Guidebook of the western United States. Part C. The Santa Fe route, with a side trip to the Grand Canyon of the Colorado. Washington D.C.: United States Geological Survey (Bulletin 613). 1915.
DAVIS, Thomas M.

Lines west! - the story of George W. Holdrege, part 3. Nebraska History, Lincoln, v.31, p.204-225. 1950.

FIGUEIRÔA, Sylvia; SILVA, Clarete da. Enlightened mineralogists: mining knowledge in colonial Brazil, 1750-1825. Osiris, v.15, Washington D.C., p.174-89. 2001.

FRANK, Thomas.

The Leviathan with tentacles of steel: railroads in the minds of Kansas Populists. Western Historical Quarterly, Logan (Utah), v.20, p.37-54. 1989.

GATES, Paul Wallace.

The Illinois Central Railroad and its colonization work. Cambridge: Harvard University Press. 1934.

GREEVER, William S.

Arid domain: the Santa Fe Railway and its western land grant. Stanford: Stanford University Press. 1954.

GRINNELL, George Bird.

An old-time bone hunt: an account of the expedition undertaken by prof. O.C. Marsh in 1870 to the then Wild West. Natural History, New York, v.23, p.329-336. 1923.

HATCHER, John Bell.

Letter to Dr. W.J. Holland. Hatcher Papers, Section of Vertebrate Paleontology (Carnegie Museum of Natural History). 2 Oct. 1901.

HATCHER, John Bell.

Letter to Dr. Holland. Hatcher Papers, Section of Vertebrate Paleontology (Carnegie Museum of Natural History). 17 July 1901.

HATCHER, John Bell.

Letter to Dr. Holland. Hatcher Papers, Section of Vertebrate Paleontology (Carnegie Museum of Natural History). 24 May 1901.

HEADRICK, Daniel.

The tentacles of progress: technology transfer in the age of imperialism, 1850-1940. New York: Oxford University Press. 1988.

HEADRICK, Daniel.

The tools of empire: technology and European imperialism in the nineteenth century. New York: Oxford University Press. 1981.

HEDGES, James B.

Promotion of immigration to the Pacific Northwest by the railroads. Mississippi Valley

Historical Review, Cedar Rapids, Iowa Bloomington, v.15, p.183-203. 1928.

HEDGES, James B. The colonization work of the Northern Pacific Railroad. Mississippi Valley Historical Review, 
Cedar Rapids, Iowa Bloomington, v.13, p.311-342. 1926.

HUBBARD, Gardiner G.

The transcontinental railroads. Science, Washington D.C., v.10, p.133-137. 1887.

JONES, C. Clyde.

A survey of the agricultural development program of the Chicago, Burlington and Quincy Railroad. Nebraska History, Lincoln, v.30, p.226-256. 1949.

KIRSCH, Scott.

John Wesley Powell and the mapping of the Colorado Plateau, 1869-1879: survey science, geographical solutions, and the economy of environmental values. Annals of the Association of American Geographers, Washington, v. 92, p.548-572. 2002.

\section{KIRSCH, Scott.}

Regions of government science: John Wesley Powell in Washington and the American West. Endeavour, Oxford, v.23, p.155-158. 1999.

LEE, Willis T.; STONE, Ralph W.; GALE, Hoyt S. Guidebook of the western United States. Part B. The overland route, with a side trip to Yellowstone Park. Washington: United States Geological Survey. (Bulletin 612). 1915.

LEIDY, Joseph.

Letter to Dr. F.V. Hayden. Hayden Survey, Miscellaneous Letters Received, entry 19, RG 57, box 1, Records of the Geological Survey, (National Archives II, College Park). 13 Aug. 1877.

LOMAX, E.L.

Letter to Prof. Aven Nelson. University of Wyoming, Botany Records, accession number 545001, box 17 (American Heritage Center, University of Wyoming). 6 Nov. 1901.

LOMAX, E.L.

Letter to Prof. Aven Nelson. University of Wyoming, Botany Records, accession number 545001, box 17 (American Heritage Center, University of Wyoming). 10 June 1901.

LOMAX, E.L.

Letter to Prof. Aven Nelson. University of Wyoming, Botany Records, accession number 545001, box 17 (American Heritage Center, University of Wyoming). 3 June 1901.

LOMAX, E.L.

Letter to Prof. Nelson. University of Wyoming, Botany Records, accession number 545001, box 17 (American Heritage Center, University of Wyoming). 26 Apr. 1901.

LOMAX, E.L.

Letter to Aven Nelson. University of Wyoming, Botany Records, accession number 545001, box 17 (American Heritage Center, University of Wyoming). 24 Apr. 1897.
MACFARLANE, James.

An American geological railway guide. New York: Appleton. 1879.

MICKELSON, Sig.

The Northern Pacific Railroad and the selling of the West: a nineteenth-century public relations venture. Sioux Falls: Center for Western Studies. 1993.

ORSI, Richard J.

Sunset limited: the Southern Pacific Railroad and the development of the American West, 1850-1930. Berkeley: University of California Press. 2005.

OVERTON, Richard C.

Burlington west: a colonization history of the Burlington Railroad. Cambridge: Harvard University Press. 1941.

PODGORNY, Irina.

Bones and devices in the constitution of paleontology in Argentina at the end of the nineteenth century. Science in Context, Cambridge, v.18, p.249-283. 2005.

POLANCO, Xavier.

World-science: how is the history of worldscience to be written? In: Petitjean, Patrick; JAMI, Catherine; MOULIN, Anne Marie (Ed.). Science and empires: historical studies about scientific development and European expansion. Dordrecht: Kluwer. p.225-242. 1992.

POLANCO, Xavier.

Une science-monde: la mondialisation de la science Européenne et la création de traditions scientifiques locales. In: Polanco, Xavier (Ed.). Naissance et développement de la science-monde: production et reproduction des communautés scientifiques en Europe et en Amérique Latine. Paris: Éditions La Découverte. p.10-52. 1990.

POPENOE, Edwin A.

A list of Kansas coleoptera. Transactions of the Kansas Academy of Science, Lawrence, v.5, p. 21-40. 1876 .

POWELL, John Wesley.

Report of the director. Annual report of the Bureau of Ethnology for 1892-1893, Washington, v.14, p. xxvii-lxi. 1896.

POWELL, John Wesley.

On the organization of scientific work of the general government: extracts from the testimony taken by the Joint Commission of the Senate and House of Representatives to consider the present organizations of the signal service, geological survey, coast and geodetic survey, and the Hydrographic Office of the Navy Department, with the view to secure greater efficiency and economy of administration. Washington: Government Printing Office. 1885. 
POWELL, John Wesley.

Report of the director. Annual report of the Bureau of Ethnology for 1880-1881, Washington, v.2, p. Xv-xxxvii. 1883.

POWELL, John Wesley.

Report of the director. Annual report of the Bureau of Ethnology for 1879-1880, Washington, v.1, p. xi-xxxiii. 1881

POWELL, John Wesley. Introduction to the study of Indian languages. 2. ed. Washington: Government Printing Office. 1880.

POWELL, John Wesley.; Ingalls, G. W. Report of special commissioners on the condition of the Ute Indians of Utah; the Paiutes of Utah, Northern Arizona, Southern Nevada, and Southeastern California; the Go-Si-Utes of Utah and Nevada; the Northwestern Shoshones of Idaho and Utah; and the Western Shoshones of Nevada; and Report concerning claims of settlers in the Moa-Pa Valley, Southeastern Nevada. Washington: Government Printing Office. 1874. Reprinted in: Don D. Fowler and Catherine S. Fowler (Eds.). Anthropology of the Numa: John Wesley Powell's manuscripts on the Numic peoples of western North America. Washington: Smithsonian Institution Press. p.97-119. 1971.

RYDBERG, P.A.

Letter to Prof. Chas. E. Bessey. Charles E. Bessey Papers (RG 12/7/10), box 10, Archives \& Special Collections (University of Nebraska-Lincoln Libraries). 13 Mar. 1900.

STROM, Claire.

Profiting from the plains: the Great Northern Railway and corporate development of the American West. Seattle: University of Washington Press. 2003.

TAYLOR, Frederick William.

Letter [per L. Bruner] to Mr. G.W. Bonnell. Lawrence Bruner Papers (RG 8/12/10), box 15 , Archives \& Special Collections (University of Nebraska-Lincoln Libraries). 3 Aug. 1896.

TAYLOR, Frederick William.

Letter to Mr. G.W. Holdrege. Frederick William Taylor Papers, MS 681, folder 4 (Nebraska State Historical Society). 2 June 1894.

TAYLOR, Frederick William.

Letter to Mr. E. St. John. Frederick William Taylor Papers, MS 681, folder 4 (Nebraska State Historical Society). 30 Jan. 1894.
TAYLOR, Frederick William.

Letter to Mr. G.W. Holdrege. Frederick William Taylor Papers, MS 681, folder 2 (Nebraska State Historical Society). 2 Dec. 1892.

TAYLOR, Frederick William.

Letter to G.W. Holdrege. Frederick William

Taylor Papers, MS 681, folder 2 (Nebraska State Historical Society). 26 Sept. 1892.

TAYLOR, Frederick William.

Letter to G.W. Holdrege. Frederick William

Taylor Papers, MS 681, folder 2 (Nebraska State Historical Society). 21 June 1892.

VETTER, Jeremy.

The regional development of science: knowledge, environment, and field work in the US Great Plains and Rocky Mountains, 1860-1920.

Dissertation (PhD) - University of

Pennsylvania, Philadelphia. 2005.

VETTER, Jeremy.

Science along the railroad: expanding field work in the US Central West. Annals of Science, London, v.61, p.187-211. 2004.

WALLERSTEIN, Immanuel.

World-systems analysis: an introduction.

Durham: Duke University Press. 2004.

WALLERSTEIN, Immanuel.

The modern world-system. New York: Academic Press. 1974.

WIDTSOE, John A.

Letter to Mr. E.W. Gillett. Utah Agricultural Experiment Station, Director's Letterbooks (J. A. Widtsoe), \#18.16:17 (Tanner Reading Room, Merrill Library, Utah State University). 30 July 1903.

WIDTSOE, John A.

Letter to Mr. E.W. Gillett. Utah Agricultural Experiment Station, Director's Letterbooks (J. A. Widtsoe), \#18.16:17 (Tanner Reading Room, Merrill Library, Utah State University). 22 July 1903.

WORSTER, Donald.

A river running west: the life of John Wesley Powell. Oxford: Oxford University Press. 2001.

ZIEDEL, Robert F.

Peopling the empire: the Great Northern Railroad and the recruitment of immigrant settlers to North Dakota. North Dakota History, Bismarck, N.D., v. 60, n. 2, p.14-23. 1993. 